\title{
A new genus and species of foliicolous lichen in a new family of Strigulales (Ascomycota: Dothideomycetes) reveals remarkable class-level homoplasy
}

\author{
Shu Hua Jiang ${ }^{1}$, David L. Hawksworth ${ }^{2,3,4}$, Robert Lücking ${ }^{5}$ and Jiang Chun Wei ${ }^{1,6^{*}}$
}

\begin{abstract}
Phylogenetic analysis of some foliicolous lichens collected in Hainan Province, China, revealed a new lineage morphologically similar to Porina but phylogenetically related to Strigulaceae (Dothideomycetes), differing from the latter in ascus type. The monospecific genus Tenuitholiascus gen. nov. is introduced for the single species, $T$. porinoides sp. nov., which is placed in the new, monogeneric family Tenuitholiascaceae, sister to Strigulaceae in Strigulales. The new taxon closely resembles the genus Porina in external morphology and ascospore type, as well as the thin-walled asci and unbranched paraphyses. Yet, it is entirely unrelated to the latter, which belongs in class Lecanoromycetes in the order Gyalectales.
\end{abstract}

Keywords: Phylloblastia, Phyllocratera, Phylloporis

\section{INTRODUCTION}

Foliicolous lichens are widespread in the tropics and extraordinarily diverse (Santesson 1952; Lücking 2001, 2008). Their small size and their tendency to occur mixed with other foliicolous lichens and non-lichenized fungi in minute communities, and in some cases their growth under the host plant cuticle, has rendered a reappraisal of the relationships of these fungi by molecular phylogenetic methods technically difficult. Yet, some chiefly foliicolous lineages such as Gomphillaceae, Pilocarpaceae, Porinaceae, and the genus Chroodiscus (Graphidaceae) have been partly studied phylogenetically (Lücking et al. 2004; Andersen and Ekman 2005; Baloch and Grube 2006, 2009; Papong et al. 2009).

The order Strigulales in class Dothideomycetes was established by Lücking et al. (in Hyde et al. 2013) for the single family Strigulaceae, in an updated phylogeny which showed that the family was separate from other clades recognized as orders. Four genera (Flavobathelium,

\footnotetext{
* Correspondence: weijc@im.ac.cn

${ }^{1}$ State Key Laboratory of Mycology, Institute of Microbiology, Chinese Academy of Sciences, Beijing, China

${ }^{6}$ University of Chinese Academy of Sciences, Beijing, China

Full list of author information is available at the end of the article
}

Phyllobathelium, Phyllocratera, Strigula) were accepted in the family at that time, but with the inclusion of the poorly known, monospecific genus Oletheriostrigula (Huhndorf and Harris 1996), that number has grown to five (Jaklitsch et al. 2016; Lücking et al. 2017). Members of this lineage are mostly found on leaves, with the most speciose genus being Strigula, and more rarely on bark and rocks, mostly in tropical to subtropical habitats, with very few species extending into temperate regions (Harris 1995; Roux et al. 2004; Aptroot and Moon 2014). Strigulales have been analysed molecularly in various studies (Nelsen et al. 2009, 2011a), particularly focusing on species delimitation in foliicolous representatives of Strigula in tropical Asia (Jayalal et al. 2013; Krishnamurthy and Subramanya 2016; Jiang et al. 2016, 2017a, 2017b; Krishnamurthy and Kumar 2017).

As part of a phylogenetic revision of species of Strigula s.lat. and similar taxa, we came across a novel lineage resembling species of Porina but clustering with Strigulales in Dothideomycetes. The diagnostic feature of this new lineage is the thin-walled ascus apex, an unusual feature for Dothideomycetes. Given that Strigulales and the related families Acrospermaceae, Dyfrolomycetaceae, and Kirschsteiniotheliaceae all have bitunicate asci with

(c) The Author(s). 2020 Open Access This article is distributed under the terms of the Creative Commons Attribution 4.0 International License (http://creativecommons.org/licenses/by/4.0/), which permits unrestricted use, distribution, and reproduction in any medium, provided you give appropriate credit to the original author(s) and the source, provide a link to the Creative Commons license, and indicate if changes were made. The Creative Commons Public Domain Dedication waiver (http://creativecommons.org/publicdomain/zero/1.0/) applies to the data made available in this article, unless otherwise stated. 
a thin but distinct tholus and ocular chamber (Huhndorf and Harris 1996; Lücking 2008; Hyde et al. 2013), we recognize this new taxon as a new genus (Tenuitholiascus) in a new family (Tenuitholiascaceae). Initially we also considered introducing a new order, but since families with different ascus types have been shown to be closely related and included in single orders in other instances, such as Lecanorales in Lecanoromycetes (Miadlikowska et al. 2014), we include the new family in the order Strigulales, related to the orders Acrospermales (Minter et al. 2007), Dyfrolomycetales (Hyde et al. 2013), and Kirschsteiniotheliales (Hernández-Restrepo et al. 2017).

\section{MATERIAL AND METHODS}

Material examined

The interesting specimens regarding the new family were all collected from Hainan province in China. All are preserved in the Fungarium-Lichenum of the Institute of Microbiology, Chinese Academy of Sciences (HMAS-L).

\section{METHODS}

Phenotypic analyses

A LEICA M125 dissecting microscope (Leica Microsystems, Singapore) was used for the morphological studies, and a Zeiss Axioscope2 (Carl Zeiss, Göttingen) compound microscope for the anatomical studies and measuring the size. Photographs were obtained with an AxioCam MRc5 connected to a Zeiss Imager A2-M2 microscope (Carl Zeiss, Göttingen) for microscopic features. Thin-layer chromatography (TLC) (Orange et al. 2001) was employed for the detection of lichen substances. The features of the ascus apex were revealed using Lugol's solution without pre-treatment by $\mathrm{KOH}$ (Baral 1987).

\section{Genotypic analyses \\ DNA extraction and PCR amplification}

All newly collected fresh specimens were subjected to DNA extraction (Table 1), for which a modified CTAB method (Rogers and Bendich 1988) was used. DNA, suspended in $\mathrm{ddH}_{2} \mathrm{O}$, was amplified by the polymerase chain reaction (PCR). Partial nuclear ribosomal small subunit SSU sequences were amplified and sequenced using combinations of the primers SF5-CAATTGGAGG GCAAGTCTGG and SR5-CCAAGAGATCCGTT GTTGAAAG (in this study). A portion of the fungal nuclear ribosomal large subunit LSU was amplified and sequenced using primers ITS3 (White et al. 1990) and

Table 1 Sequences for molecular phylogenetic analysis in Strigulales. The new sequences generated were in bold

\begin{tabular}{|c|c|c|c|c|c|}
\hline \multirow[t]{2}{*}{ Species } & \multirow[t]{2}{*}{ Species No. } & \multicolumn{4}{|c|}{ GenBank Accession No. (LSU, SSU, TEF1-a, RPB2) } \\
\hline & & $\overline{L S U}$ & SSU & TEF1- $a$ & RPB2 \\
\hline Flavobathelium epiphyllum & MPN67 & GU327717 & JN887382 & JN887423 & - \\
\hline Phyllobathelium anomalum & MPN242 & GU327722 & JN887386 & JN887430 & - \\
\hline Tenuitholiascus porinoides sp. nov. & HMAS_L0139638 & MK206259 & MK352441 & MK273106 & MK273134 \\
\hline T. porinoides sp. nov. & HMAS_L0139639 & MK206258 & MK352442 & MK273105 & MK273133 \\
\hline T. porinoides sp. nov. & HMAS_L0139640 & MK206260 & MK352443 & MK273107 & MK273135 \\
\hline Strigula acuticonidiarum & HMAS_L0138045 & MK206236 & MK206217 & MK273083 & MK273111 \\
\hline S. guangxiensis & HMAS_L0138040 & MK206256 & - & MK273103 & MK273131 \\
\hline S. guangxiensis & HMAS_L0138041 & MK206257 & - & MK273104 & MK273132 \\
\hline S. cf. macaronesica & HMAS_L0130615 & MK206251 & MK206230 & MK273098 & MK273126 \\
\hline S. cf. macaronesica & HMAS_L0139260 & MK206252 & MK206231 & MK273099 & MK273127 \\
\hline S. macrocarpa & HMAS_L0141394 & MK206240 & MK206221 & MK273087 & MK273115 \\
\hline S. macrocarpa & HMAS_L0139289 & MK206241 & MK206222 & MK273088 & MK273116 \\
\hline S. nemathora & MPN72 & JN887405 & JN887389 & JN887433 & - \\
\hline S. nitidula & HMAS_L0139358 & MN788374 & MN788375 & MN793983 & MN793982 \\
\hline S. sinoaustralis & HMAS_L0137204 & MK206249 & - & MK273096 & MK273124 \\
\hline S. cf. smaragdula & HMAS_L0141395 & MK206234 & MK206215 & MK273081 & MK273109 \\
\hline S. cf. smaragdula & HMAS_L0141396 & MK206233 & MK206214 & MK273080 & MK273108 \\
\hline S. cf. smaragdula & HMAS_L0139166 & MK206235 & MK206216 & MK273082 & MK273110 \\
\hline S. univelbiserialis & HMAS_L0137657 & MK206243 & MK206224 & MK273090 & MK273118 \\
\hline S. univelbiserialis & HMAS_L0137658 & MK206245 & MK206226 & MK273092 & MK273120 \\
\hline S. univelbiserialis & HMAS_L0137659 & MK206242 & MK206223 & MK273089 & MK273117 \\
\hline S. univelbiserialis & HMAS_L0137660 & MK206244 & MK206225 & MK273091 & MK273119 \\
\hline
\end{tabular}


LR72-TACTACCACCAAGATCTGCAC. Partial TEF1- $\alpha$ sequences were generated using the primers TEF1a-983 F (Rehner and Buckley 2005) and TEF1a-1567R-HTL (Nelsen et al. 2011a). The second largest subunit of RNA polymerase II, RPB2, was amplified and sequenced using primers: fRPB2-5F-GAYGAYMGWGATCAYTTYGG and fRPB27cR- CCCATRGCTTGYTTRCCCAT (Liu et al. 1999).

Photosymbionts of selected specimens were also analyzed phenotypically and molecularly besides phenotype (Table 2). ITS nrDNA sequences of the algal partners were amplified and sequenced using the primers $\mathrm{nr}$ SSU-1780-59 and nr-LSU-0012-39 (Piercey-Normore and Depriest 2001).

PCR reactions were carried out in $25 \mu \mathrm{l}$ reaction volumes and the components used were: $2 \mu$ l total DNA, $1 \mu \mathrm{l}$ each primer $(10 \mu \mathrm{M}), 12.5 \mu \mathrm{l} 2 \times$ Taq MasterMix,

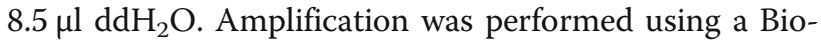
metra T-Gradient thermal cycler. Cycling parameters for LSU, ITS and SSU were set to an initial denaturation at $95^{\circ} \mathrm{C}$ for $5 \mathrm{~min}$, followed by 35 cycles of denaturation at $94{ }^{\circ} \mathrm{C}$ for $30 \mathrm{~s}$, annealing at $54^{\circ} \mathrm{C}$ for $30 \mathrm{~s}$, extension at $72{ }^{\circ} \mathrm{C}$ for $1 \mathrm{~min}$, and a final extension at $72{ }^{\circ} \mathrm{C}$ for 10 min. PCR amplifications of TEF1- $\alpha$ were initiated with a 2 min denaturation at $94^{\circ} \mathrm{C}$. The annealing temperature in the first amplification cycle was $66^{\circ} \mathrm{C}$, which was subsequently incrementally reduced by $1{ }^{\circ} \mathrm{C}$ per cycle over the next 9 cycles. An additional 30 amplification cycles were then performed, each consisting of $30 \mathrm{~s}$ denaturation at $94{ }^{\circ} \mathrm{C}$, a $30 \mathrm{~s}$ annealing step at $56^{\circ} \mathrm{C}$, and a $1 \mathrm{~min}$ extension at $72{ }^{\circ} \mathrm{C}$, concluding with a 10 min incubation at $72{ }^{\circ} \mathrm{C}$ (Rehner and Buckley 2005). The PCR conditions of RPB2 included: initial denaturation at $95^{\circ} \mathrm{C}$ for $5 \mathrm{~min}$; 35 cycles of $1 \mathrm{~min}$ at $95^{\circ} \mathrm{C}, 2 \mathrm{~min}$ at $50^{\circ} \mathrm{C}$, an increase of $1{ }^{\circ} \mathrm{C} / 5 \mathrm{~s}$ to $72{ }^{\circ} \mathrm{C}$, and $2 \mathrm{~min}$ at $72^{\circ} \mathrm{C}$; and a $10 \mathrm{~min}$ incubation at $72{ }^{\circ} \mathrm{C}$ (Liu et al. 1999). PCR products were checked on $0.8 \%$ agarose electrophoresis gels stained with ethidium bromide and then sent to the sequencing facilities of Majorbiology (Changping district, Beijing, China), for sequencing.

\section{Sequence alignment and phylogenetic analyses}

For the mycobionts, sequences generated from different primers (Table 1) were analyzed with others obtained from the GenBank (Table 3). To determine the exact placement of the new lineage, a three-locus (SSU, LSU, and TEF- $\alpha$ ) dataset was compiled in which sequences were aligned with those retrieved from GenBank covering the main groups of the class Dothideomycetes. In total, 109 ingroup taxa were used together with four outgroup taxa representing Arthoniomycetes. Further, a four-locus (SSU, LSU, TEF- $\alpha$, and RPB2) dataset was also analysed with those retrieved from GenBank covering Dothideomycetes and Lecanoromycetes of the phylum Ascomycota, with three outgroup taxa representing $\mathrm{Ba}$ sidiomycota (Table 3). For the datasets, we only used specimens with the highest number of available markers. Each partition of LSU, SSU, TEF1- $\alpha$, and RPB2 was aligned independently and then the alignments were concatenated for multi-locus analyses. Generated ITS sequences of algal partners were aligned with eight samples of Trentepohliaceae from GenBank (Table 2). All sequences were aligned with MAFFT v7.402 (Katoh and Toh 2010).

An ML tree involving 1000 pseudoreplicates was generated by IQ-TREE v1.6.6 (Nguyen et al. 2015) using the shared set of 3 or 4 genes. For this analysis, the bestfit substitution model was selected using ModelFinder (Kalyaanamoorthy et al. 2017), which identifies optimal model of sequence evolution (SE) by combining substitution models (e.g. GTR) with flexible rate heterogeneity

Table 2 Sequences of photobiont Trentepohliaceae. The new sequences generated were in bold

\begin{tabular}{lll}
\hline Species & Species No. & GenBank Accession No.(ITS) \\
\hline Cephaleuros expansus & GD1318 & KX586811 \\
Cephaleuros karstenii & DZ1309 & KX586781 \\
Cephaleuros karstenii & DZ1312 586784 \\
Cephaleuros sp. from Strigula sp. & HMAS_L0130622 & MK211171 \\
Cephaleuros sp. from S. cf. smaragdula & HMAS_L0141395 & MK211172 \\
Phycopeltis aurea & YN1220 & KP067280 \\
Phycopeltis sp. from Tenuitholiascus porinoides sp. nov. & HMAS_L0139638 & MK211174 \\
Phycopeltis sp. from T. porinoides sp. nov. & HMAS_L0141346 & MK211173 \\
Phycopeltis sp. & YN1202 & KP067279 \\
Trentepohlia sp. & DS22 & KC489115 \\
Trentepohlia sp. & SAG 118.80 & KM020078 \\
Trentepohlia sp. & TreFl54 & KC489121 \\
Ulva tepida & PR18 & KT374011
\end{tabular}


Table 3 Other sequences retrieved from GenBank for phylogenetic analysis

\begin{tabular}{|c|c|c|c|c|}
\hline \multirow[t]{2}{*}{ Species } & \multicolumn{4}{|c|}{ GenBank Accession No. (LSU, SSU, TEF1-a, RPB2) } \\
\hline & LSU & SSU & TEF1- $a$ & RPB2 \\
\hline Acarospora cervina & AY640941 & AY640982 & - & AY641021 \\
\hline Acarospora laqueata & AY640943 & AY640984 & - & AY641024 \\
\hline Acrospermum adeanum & EU940104 & EU940031 & - & EU940320 \\
\hline Acro. compressum & EU940084 & EU940012 & - & EU940301 \\
\hline Acro. gramineum & EU940085 & EU940013 & - & EU940302 \\
\hline Aigialus grandis & GU301793 & GU296131 & - & GU371762 \\
\hline Aigialus parvus & GU301795 & GU296133 & GU349064 & GU371771 \\
\hline Aliquandostipite khaoyaiensis & GU301796 & AF201453 & GU349048 & FJ238360 \\
\hline Anisomeridium ubianum & GU327709 & JN887379 & - & - \\
\hline Apiosporina collinsii & GU301798 & GU296135 & GU349057 & - \\
\hline Armillaria mellea & AY700194 & AY787217 & AY881023 & AY780938 \\
\hline Aquasubmersa japonica & LC061588 & LC061583 & LC194385 & LC194422 \\
\hline Arthopyrenia salicis & AY538339 & AY538333 & - & - \\
\hline Ascocratera manglicola & GU301799 & GU296136 & - & GU371763 \\
\hline Asterina cestricola & GU586215 & GU586209 & - & - \\
\hline As. fuchsiae & GU586216 & GU586210 & - & - \\
\hline As. phenacis & GU586217 & GU586211 & - & - \\
\hline As. weinmanniae & GU586218 & GU586212 & - & - \\
\hline As. zanthoxyli & GU586219 & GU586213 & - & - \\
\hline Aureobasidium pullulans & DQ470956 & DQ471004 & DQ471075 & DQ470906 \\
\hline Botryobambusa fusicoccum & JX646809 & JX646826 & - & - \\
\hline Botryosphaeria agaves & JX646808 & JX646825 & - & - \\
\hline Botryosphaeria dothidea & DQ678051 & DQ677998 & DQ767637 & DQ677944 \\
\hline Calocera cornea & AY701526 & AY771610 & AY881019 & AY536286 \\
\hline Cladonia caroliniana & AY584640 & AY584664 & DQ782888 & AY584684 \\
\hline Cladonia stipitata & DQ973026 & DQ973003 & - & DQ973087 \\
\hline Coccocarpia erythroxyli & DQ883800 & DQ883791 & DQ883775 & DQ883756 \\
\hline Delitschia didyma & DQ384090 & AF242264 & - & - \\
\hline Delitschia winteri & DQ678077 & DQ678026 & DQ677922 & DQ677975 \\
\hline Dendrographa decolorans & AY548815 & AY548809 & DQ883725 & \\
\hline Dothidea hippophaeos & DQ678048 & U42475 & DQ677887 & DQ677942 \\
\hline D. insculpta & DQ247802 & DQ247810 & DQ471081 & AF107800 \\
\hline D. sambuci & AY544681 & AY544722 & DQ497606 & KT216559 \\
\hline Dothiora cannabinae & DQ470984 & DQ479933 & DQ471107 & DQ470936 \\
\hline Dyfrolomyces rhizophorae & GU479799 & GU479766 & GU479860 & - \\
\hline Dyfrolomyces tiomanensis & KC692156 & KC692155 & KC692157 & - \\
\hline Elsino centrolobi & DQ678094 & DQ678041 & DQ677934 & - \\
\hline E. phaseoli & DQ678095 & DQ678042 & DQ677935 & - \\
\hline E. veneta & DQ767658 & DQ767651 & DQ767641 & - \\
\hline Falciformispora lignatilis & GU371826 & GU371834 & GU371819 & - \\
\hline Fal. senegalensis & KF015627 & KF015634 & KF015688 & KF015716 \\
\hline Fal. tompkinsii & KF015625 & KF015640 & KF015685 & KF015718 \\
\hline Flavoparmelia caperata & AY584639 & AY584663 & DQ883763 & AY584685 \\
\hline
\end{tabular}


Table 3 Other sequences retrieved from GenBank for phylogenetic analysis (Continued)

\begin{tabular}{|c|c|c|c|c|}
\hline \multirow[t]{2}{*}{ Species } & \multicolumn{4}{|c|}{ GenBank Accession No. (LSU, SSU, TEF1-a, RPB2) } \\
\hline & LSU & SSU & TEF1- $a$ & RPB2 \\
\hline Fomitopsis pinicola & AY684164 & AY705967 & AY885152 & AY786056 \\
\hline Gibbera conferta & GU301814 & GU296150 & GU349041 & - \\
\hline Gloniopsis praelonga & FJ161195 & FJ161154 & FJ161103 & FJ161113 \\
\hline Glonium circumserpens & FJ161200 & FJ161160 & FJ161108 & FJ161126 \\
\hline Glonium stellatum & FJ161179 & FJ161140 & FJ161095 & - \\
\hline Guignardia gaultheriae & DQ678089 & - & - & \\
\hline Heterodermia vulgaris & KX512857 & DQ883789 & DQ883773 & DQ883754 \\
\hline Hysteropatella clavispora & AY541493 & DQ678006 & DQ677901 & DQ677955 \\
\hline Jahnula aquatica & EF175655 & EF175633 & - & - \\
\hline J. bipileata & EF175657 & EF175635 & - & - \\
\hline Kirschsteiniothelia aethiops & AY016361 & AY016344 & DQ677884 & DQ470914 \\
\hline Kirschsteiniothelia lignicola & HQ441568 & HQ441569 & - & - \\
\hline Lecanactis abietina & AY548812 & AY548805 & - & \\
\hline Lecanora contractula & DQ986746 & DQ986741 & - & DQ992428 \\
\hline Lepidosphaeria nicotiae & DQ678067 & - & DQ677910 & DQ677963 \\
\hline Lichenoconium aeruginosum & HQ174269 & - & - & - \\
\hline L. erodens & HQ174267 & - & - & - \\
\hline L. lecanorae & HQ174263 & - & - & - \\
\hline L. usneae & HQ174265 & - & - & - \\
\hline Lichenothelia calcarea & KC015061 & KC015081 & - & - \\
\hline Lichenothelia convexa & KC015068 & KC015083 & - & - \\
\hline Lindgomyces breviappendiculata & AB521748 & AB521733 & - & - \\
\hline Lindgomyces ingoldianus & AB521736 & AB521719 & - & - \\
\hline Lobariella pallida & DQ883797 & DQ883788 & DQ883772 & DQ883753 \\
\hline Lophiotrema neoarundinaria & AB524596 & AB524455 & AB539110 & AB539097 \\
\hline Macrophomina phaseolina & DQ678088 & DQ678037 & DQ677929 & KX463996 \\
\hline Massariosphaeria grandispora & GU301842 & GU296172 & GU349036 & GU371725 \\
\hline Massariosphaeria typhicola & GU301844 & GU296174 & - & GU371795 \\
\hline Megalotremis verrucosa & GU327718 & JN887383 & - & - \\
\hline Microthyrium microscopicum & GU301846 & GU296175 & GU349042 & GU371734 \\
\hline Microxyphium aciculiforme & GU301847 & GU296176 & GU349045 & GU371736 \\
\hline Microxyphium theae & GU301849 & GU296178 & GU349060 & - \\
\hline Myelochroa aurulenta & EF042917 & DQ973001 & - & DQ973070 \\
\hline Myriangium duriaei & DQ678059 & AY016347 & DQ677900 & DQ677954 \\
\hline Myriangium hispanicum & GU301854 & GU296180 & GU349055 & GU371744 \\
\hline Mytilinidion resinicola & FJ161185 & FJ161145 & - & - \\
\hline Mytilinidion scolecosporum & FJ161186 & FJ161146 & FJ161102 & FJ161121 \\
\hline Natipusilla bellaspora & $J \times 474863$ & JX474868 & - & - \\
\hline N. decorospora & HM196369 & HM196376 & - & - \\
\hline N. limonensis & HM196370 & HM196377 & - & - \\
\hline N. naponensis & HM196372 & HM196379 & - & - \\
\hline Neofusicoccum parvum & AY928045 & EU673151 & - & FJ900618 \\
\hline Neofusicoccum ribis & DQ678053 & DQ678000 & DQ677893 & EU339554 \\
\hline
\end{tabular}


Table 3 Other sequences retrieved from GenBank for phylogenetic analysis (Continued)

\begin{tabular}{|c|c|c|c|c|}
\hline \multirow[t]{2}{*}{ Species } & \multicolumn{4}{|c|}{ GenBank Accession No. (LSU, SSU, TEF1-a, RPB2) } \\
\hline & $\overline{L S U}$ & SSU & TEF1-a & RPB2 \\
\hline Oedohysterium insidens & GQ221882 & GU323190 & - & GU371785 \\
\hline Ophiosphaerella sasicola & AB524599 & AB524458 & AB539111 & AB539098 \\
\hline Parmotrema austrosinense & DQ912338 & DQ912315 & - & DQ912386 \\
\hline Peltigera degenii & KX869856 & AY584681 & DQ782897 & - \\
\hline Phaeotrichum benjaminii & AY004340 & AY016348 & DQ677892 & DQ677946 \\
\hline Phyllosticta citricarpa & GU301815 & GU296151 & GU349053 & \\
\hline Physconia muscigena & DQ912344 & DQ912321 & - & DQ912393 \\
\hline Platismatia glauca & KJ766626 & KJ766768 & - & DQ912388 \\
\hline Pleopsidium chlorophanum & DQ842017 & DQ525541 & DQ782920 & DQ525442 \\
\hline Pleopsidium gobiense & DQ883698 & DQ525573 & DQ883804 & DQ525452 \\
\hline Protoparmeliopsis muralis & KJ766634 & - & - & KU935052 \\
\hline Pseudotetraploa curviappendiculata & AB524608 & AB524467 & - & - \\
\hline Rasutoria tsugae & EF114705 & EF114730 & - & - \\
\hline Roccella fuciformis & AY584654 & AY584678 & - & \\
\hline Roccella montagnei & GU138014 & AF110341 & - & \\
\hline Roussoella hysterioides & AB524622 & AB524481 & AB539115 & AB539102 \\
\hline Roussoella pustulans & AB524623 & AB524482 & AB539116 & AB539103 \\
\hline Sydowia polyspora & DQ678058 & DQ678005 & DQ677899 & DQ677953 \\
\hline Trichodelitschia bisporula & GU348996 & GU349000 & GU349020 & GU371802 \\
\hline Trichodelitschia munkii & DQ384096 & DQ384070 & - & - \\
\hline Triplosphaeria maxima & AB524637 & AB524496 & - & - \\
\hline Ulospora bilgramii & DQ678076 & DQ678025 & DQ677921 & DQ677974 \\
\hline Umbilicaria papulosa & DQ883691 & DQ883701 & DQ883727 & DQ883708 \\
\hline Umbilicaria pustulata & AY300839 & DQ883700 & DQ883726 & DQ883707 \\
\hline Umbilicaria spodochroa & DQ986773 & DQ986707 & - & KY972682 \\
\hline Usnea strigosa & DQ973033 & DQ973008 & - & DQ973095 \\
\hline Venturia inaequalis & GU301878 & GU296204 & GU349023 & - \\
\hline Vulpicida pinastri & DQ923675 & DQ912318 & - & DQ912390 \\
\hline Westerdykella cylindrica & AY004343 & AY016355 & DQ497610 & - \\
\hline Westerdykella ornata & GU301880 & GU296208 & GU349021 & GU371803 \\
\hline
\end{tabular}

across sites model. By allowing the tree topology to vary during the search for an optimal model of SE, ModelFinder reduces the chance of entrapment in local optima during model selection. GTR + F + I + G4 was selected as our best model.

The Bayesian analyses were performed in MrBayes (Ronquist et al. 2012) assuming a general time reversible model including estimation of invariant sites and a discrete gamma distribution with six rate categories $(G T R+I+G)$ for the single-genes and the combined analyses. A run with 5.0 million generations to ensure the average standard deviation of split frequencies lower than 0.01 and employing 20 simultaneous chains was executed. Posterior probabilities above $90 \%$ and bootstrap support above 50\% are considered significant supports. Every method of analysis for the single-genes and the combined analysis resulted in basically the same tree.

Phylogenetic trees were drawn using FigTree v1.4.2 (Rambaut 2012). The alignments and trees were deposited in TreeBase (http://treebase.org).

\section{RESULTS}

\section{Phenotypic analyses}

In the new lineage discovered on Hainan island, the thallus was supracuticular and easily separated from the leaf surface and had a Phycopeltis-like photobiont (Fig. 1). The asci were bitunicate in structure, but the ascus apex differed from that of Strigula in lacking a thickened 

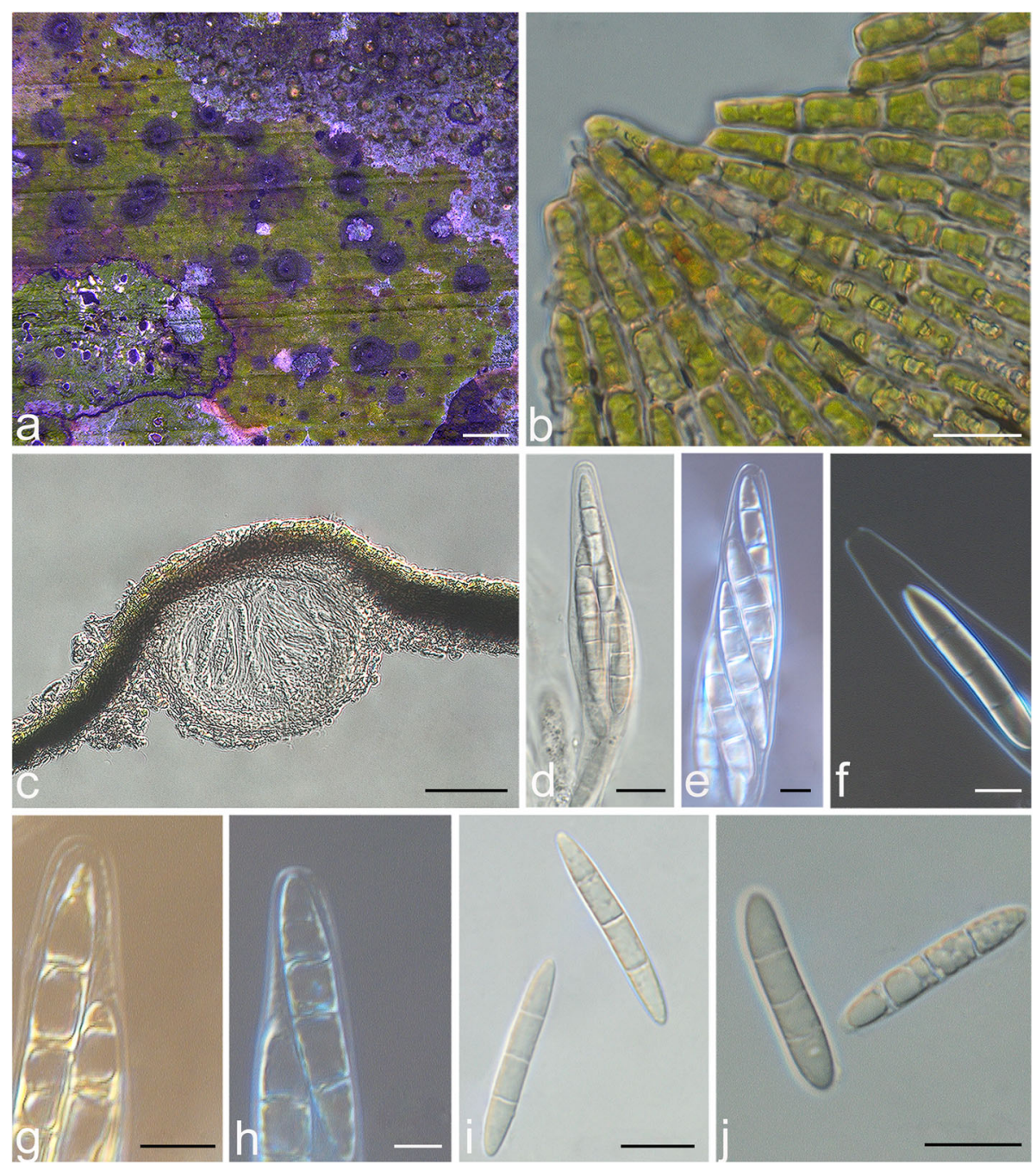

Fig. 1 Tenuitholiascus porinoides (HMAS-L0139638). a Thallus. b The Phycopeltis algal partner. c Perithecia in vertical section. d Ascus (HMASL0139639). e Ascus (HMAS-L0139640). f Ascus apex (HMAS-L0141346). g Ascus with iodine reaction (HMAS-L0139638). h Ascus with iodine reaction (HMAS-L0141348). i Ascospores (HMAS-L0139639). j Ascospores (HMAS-L0139638). Scale bars: $\mathbf{a}=300 \mu \mathrm{m}, \mathbf{b}=10 \mu \mathrm{m}, \mathbf{c}=20 \mu \mathrm{m}, \mathbf{d}, \mathbf{i}$, $\mathbf{j}=10 \mu \mathrm{m}, \mathbf{e}-\mathbf{h}=5 \mu \mathrm{m}$

tholus and ocular chamber; instead, the ascus apex had an inconspicuous non-amyloid dome. The ascospores were oblong, 3-septate, with thin septa and walls, and colorless (Figs. 1, 2). This taxon was therefore considered different from any of the five genera currently recognized within Strigulales: from all five genera in the ascus type, from most species of Strigula (except the $S$. phyllogena group) in the supracuticular growth, from Flavobathelium, which produces similar ascospores, in the general habit, with exposed perithecia, from Phyllocratera, which looks superficially similar, in the very different ascospores, from Phyllobathelium in general habit (exposed perithecia) and ascospores, and from Oletheriostrigula in the lichenized habit and the ascospore type (Huhndorf and Harris 1996; Lücking 2008). These differences, together with the deviating ascus type, not only rendered the new lineage different from Strigulaceae but also implied an unknown position within Ascomycota, with some features also pointing to genera such as Porina in Lecanoromycetes (see below).

\section{Genotypic analyses}

The dataset, including 19 LSU sequences, 16 SSU sequences, 19 TEF1- $\alpha$ sequences, and 19 RPB2 sequences newly generated for this study, was complemented with other sequences from different classes retrieved from GenBank (Table 3).

For the concatenated analysis of the three selected markers, SSU, LSU, and TEF1- $\alpha$, the individual datasets did not show supported conflicts, and so the three loci were combined. The resulting tree showed the new lineage in a well-supported sister group relationship with 

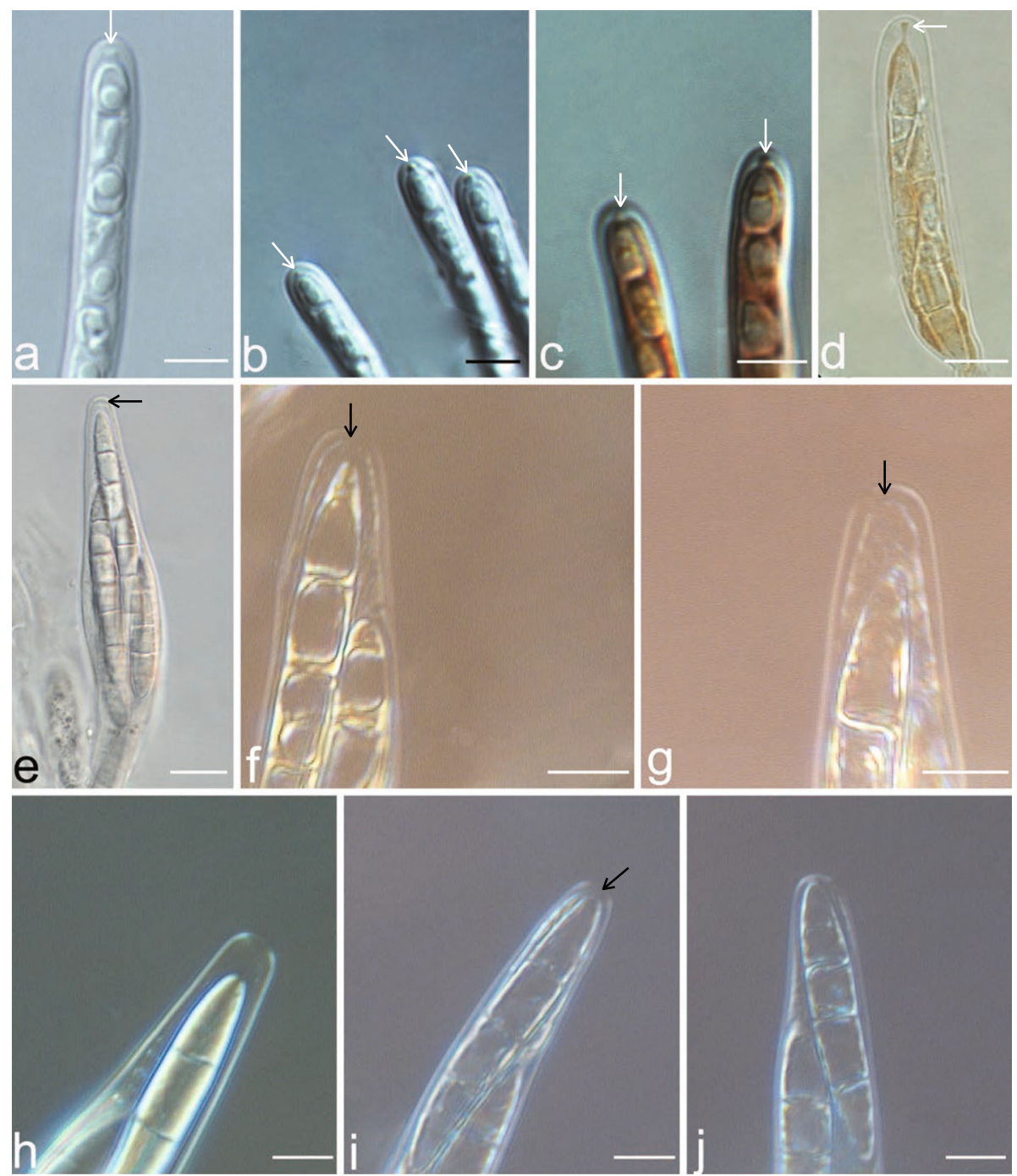

Fig. 2 Strigula nitidula (HMAS-L0139358): a-b Ascus. c Ascus showing iodine reaction in Lugol's solution. Strigula cf. smaragdula GD2015025-5 (HMAS-L0138067): d Ascus showing iodine reaction in Lugol's solution. Tenuitholiascus porinoides (e-g HMAS-L0139638; h-j HMAS-L0141348) e Ascus. $\mathbf{f}-\mathbf{g}$ Ascus with iodine reaction in Lugol's solution. $\mathbf{h}$ Ascus. $\mathbf{i}-\mathbf{j}$ Ascus with iodine reaction in Lugol's solution. White arrows indicate the ocular chamber, and black arrows indicate the non-amyloid dome. Scale bars: $a-c=5 \mu \mathrm{m}, d=10 \mu \mathrm{m}, \mathrm{e}-\mathrm{j}=5 \mu \mathrm{m}$

Strigulaceae (Fig. 3), with the following groups forming further external lineages in a supported clade: Acrospermales, Dyfromycetales, Monoblastiales, and Kirschsteiniotheliales (Fig. 3). The relationships between these lineages were not supported, except for Acrospermales and Dyfromycetales forming a strongly supported clade. This appears to be the first study that places the lichenized Monoblastiales rather close to Strigulales, which is notable as both clades share important characters and have been considered closely related or even belonging in the same family in the past (e.g. Harris 1975; Lücking 2008).

To assess placement of the new lineage within Dothideomycetes, a dataset consisting of four loci (SSU, LSU, TEF1- $\alpha$, and RPB2) was also constructed and analysed (Additional file 1). It is evident that the new lineage is a member of the class Dothideomycetes, rather than Lecanoromycetes. Also in this analysis, the specimens of the new genus formed a separate clade supported sister to the known genera of Strigulales.

In the ITS tree of the analysed photobionts, the photobiont of the new lineage clustered with algae identified as Phycopeltis, with Cephaleuros and Trentepohlia forming separate branches with high support (Fig. 4), supporting our phenotypic assessment of the photobiont as Phycopeltis.

\section{DISCUSSION}

The phenotype and molecular data demonstrate that the material from Hainan island represents a previously unknown lineage of foliicolous lichens which merits the 


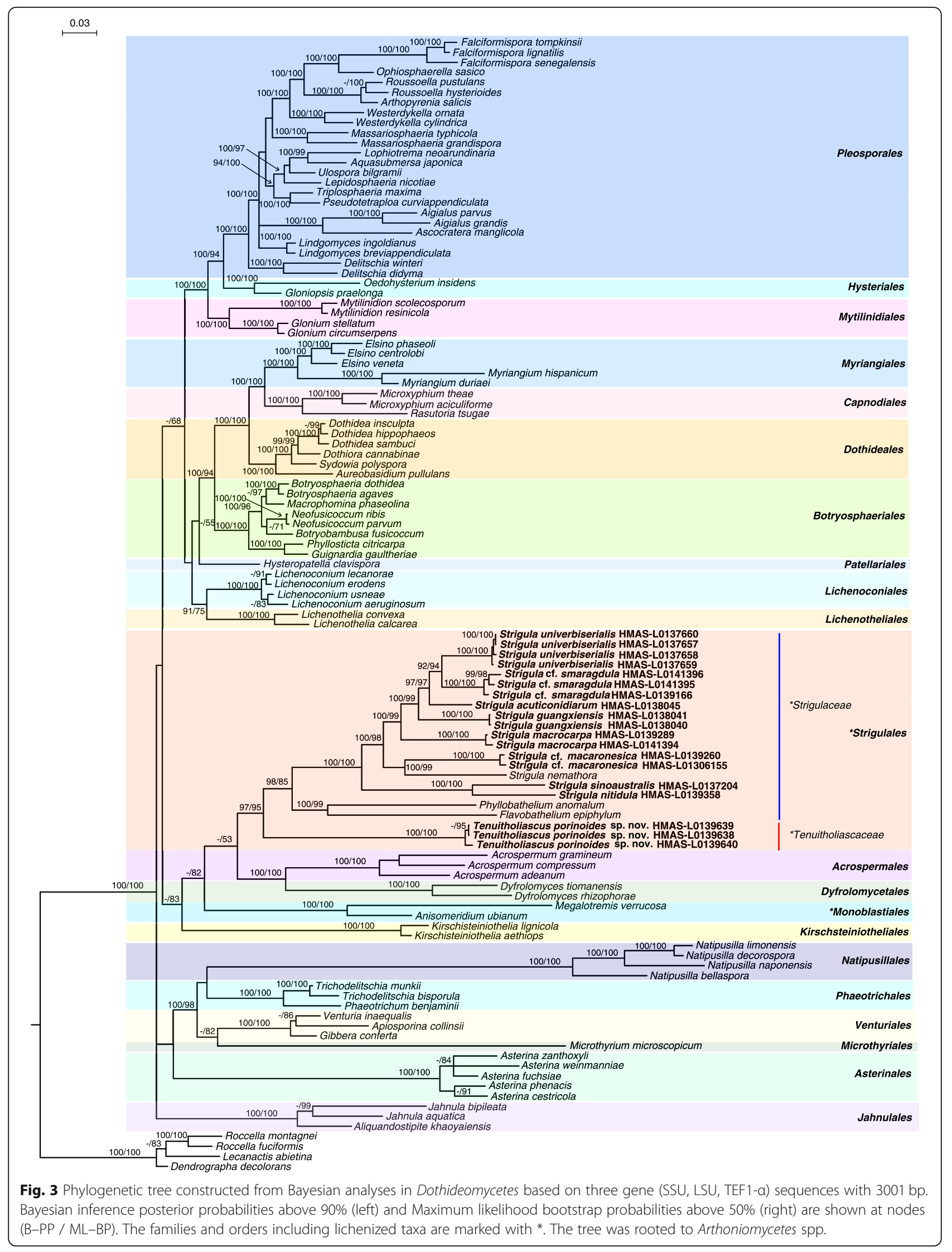




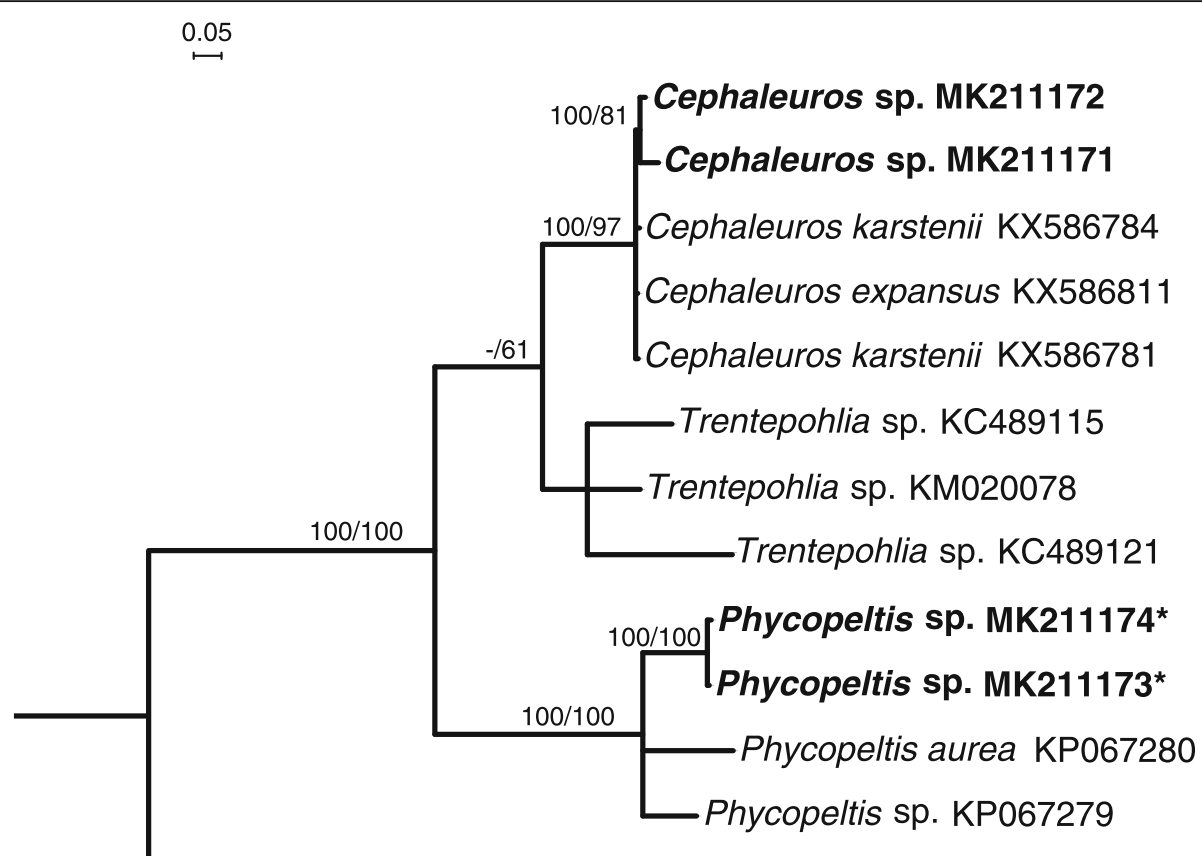

Ulva tepida KT374011

Fig. 4 Phylogenetic tree constructed from Bayesian analyses based on ITS of photobionts of Trentepohliaceae. Bayesian posterior probabilities (BPP) $>90 \%$, and Maximum likelihood bootstrap proportions $>50 \%$ are shown at nodes (B-PP / ML-BP). The new sequences generated in this study are in bold, and algal partners from Tenuitholiascus porinoides are marked with *

status of a new genus and family. The lineage is closely related to Strigulaceae but differs clearly in the ascus type. Phenotypically, the new taxon bears some resemblance with members of Strigulaceae, but also with some unrelated lichenized lineages in the Lecanoromycetes and Eurotiomycetes. Thus, the general habit with supracuticular growth, a Phycopeltis photobiont, and exposed perithecia resembles that of the Strigula phyllogena group (Lücking 2008) and of Phyllocratera (Lücking and Sérusiaux 2013), whereas the ascospores are similar to those of Flavobathelium (Lücking 2008). The comparatively thin-walled asci, together with the unbranched paraphyses and the oblong, thin-walled, 3-septate ascospores would place the new taxon close to Porina, in particularly the black-fruited species also recognized in the genera Pseudosagedia and/or Trichothelium (Harris 1995; Lücking 2008; Lücking et al. 2017; Sobreira et al. 2018). Among Porina s.lat., the most similar foliicolous species is $P$. chrysophora (Santesson 1952), which agrees in the black, hemispherical perithecia and the 3-septate ascospores, but differs in the dispersed thallus, the absence of a basally expanding perithecial wall, and the much smaller ascospores. Some foliicolous species of Phylloblastia (Eurotiomycetes: Verrucariales) previously classified in the genus Pocsia (Lücking 2008) are also superficially similar and may produce 3-septate ascospores; however, they are easily set apart by the lack of paraphyses, the apically thick-walled asci, and the different photobiont usually consisting of more rounded cells in irregular arrangement.

The apical ascus structure in all previously recognized members of Strigulales is the so-called Strigula-type, characterized by structurally bitunicate asci with a short tholus and small ocular chamber (Fig. 2a-d). The asci of the new lineage are similar to those of Strigulales in being bitunicate, but differ in their apical structure, in that the asci have an inconspicuous, non-amyloid dome lacking an ocular chamber (Fig. $2 \mathrm{e}-\mathrm{j}$ ). In some stages of development, the inner wall layer becomes gradually thinner and makes the asci appear unitunicate, similar to the genus Porina (Fig. 2h, j).

Although the overall features of the new genus show affinities to other genera currently included in Strigulaceae, the difference in ascus structure is more fundamental and merits recognition of the new taxon at a rank higher than genus. We even pondered the possibility establishing a separate order, but felt this level too high considering that likely many other lineages in this assemblage await discovery. Even foliicolous lichens remain much understudied, as illustrated by the fact that the new genus was quite abundant in the type locality and was collected multiple times during a single day. Also, there are other examples in which taxa with deviating ascus types are classified within a single order, such as Baeomycetales and Lecanorales within Lecanoromycetes (Lumbsch et al. 2007; Miadlikowska et al. 2014). 
Our three-locus based analyses (Fig. 3) provided an important insight into the phylogenetic adscription of the order Strigulales amongst Dothideomycetes, the members of which are generally characterized by thin interascal filaments. Our phylogeny largely matches that of Hyde et al. (2013) in the close relationship of Strigulaceae with Acrospermaceae (Acrospermales), Dyfrolomycetaceae (Dyfrolomycetales), and Kirschsteiniotheliaceae (Kirschsteiniotheliales). All four families clustered with strong support in a single clade, which also included the new lineage close to Strigulaceae and the Monoblastiaceae (Monoblastiales). The latter comes as surprise, as this family had not been recovered as not closely related in other analyses (Nelsen et al. 2009, 2011a; Hyde et al. 2013). All families have different morphologies and life styles, Tenuitholiascaceae being closest to Strigulaceae in these aspects but differing from all other lineages in the ascus type. Ascospores in the new lineage are most similar to those of Strigulaceae (Flavobathelium); Arcospermaceae have filiform spores, Kirschsteiniotheliaceae 1-septare but brown spores, and Dyfrolomycetaceae muriform spores (somewhat similar to Phyllobathelium but in shape more similar to those of Strigula). We therefore propose to recognize the new genus under a new family within Strigulales.

\section{TAXONOMY}

Tenuitholiascaceae S.H. Jiang, Lücking \& J.C. Wei, fam. nov. - Fungal Names FN570578;

Type: Tenuitholiascus S.H. Jiang, Lücking \& J.C. Wei.

Diagnosis: Distinguished from Strigulacaeae in the structure of the ascus apex, which lacks the short tholus and ocular chamber characteristic of Strigula-type asci. In the nuLSU alignment (Additional file 2), the following positions are consistently diagnostic at family level: 113 (A vs. G), 143 (A vs. G), 166 (C vs. G), 168 (G vs. T), 207-208 (AT vs. GC), 313 (T vs. C), 363-364 (TC vs. GT), 377 (A vs. G), 385 (T vs. C), 397 (A vs. C), 449 (T vs. G), 484-485 (TG vs. CC), 505 (T vs. C).

Tenuitholiascus S.H. Jiang, Lücking \& J.C. Wei, gen. nov. - Fungal Names FN570581;

Etymology. From the Latin tenuis- (slender), the Latin tholus (dome), and the Latin ascus (tube, bag), conveys an important feature of the apically thin-walled asci.

Type: Tenuitholiascus porinoides S.H. Jiang, Lücking \& J.C. Wei.

Diagnosis: The only genus of the family, distinguished from Strigulaceae in ascus structure (see above), from the Strigula phyllogena group also in the 3-septate, oblong ascospores, from Phyllocratera in the small, 3septate ascospores, and from Flavobathelium in the external habit with exposed perithecia.

Tenuitholiascus porinoides S.H. Jiang, Lücking \& J.C. Wei, sp. nov. - Fungal Names FN570580; Fig. 1

Etymology. The specific epithet conveys the similarity with the genus Porina, although not related to the latter.

Type: China: Hainan: Changjiang county, Bawangling National Nature Reserve, $19^{\circ} 07^{\prime} 07^{\prime \prime} \mathrm{N}, 109^{\circ} 09^{\prime} 12^{\prime \prime} \mathrm{E}$, alt. $700 \mathrm{~m}$, on living leaves, 4 Sept. 2017, S.H. Jiang HN20171851 (HMAS-L0139638 - holotype).

Description: Thallus supracuticular, easily separated from the leaf surface, continuous, smooth, pale green, 3-12 mm diam, 30-52.5 $\mu \mathrm{m}$ thick. Algal partner: Phycopeltis, cells rectangular, $8-14 \times 3-5 \mu \mathrm{m}$, composed of anastomosing filaments lying in one layer and forming regular radial plates or irregular nets. Ascomata perithecia, globose, scattered or clustered, exposed but covered by thin thallus layer up to the ostiole, central part wart-shaped, sometimes basal part broadly spreading to form horizontal plate, $0.25-0.5 \mathrm{~mm}$ diam and $80-150 \mu \mathrm{m}$ high, greyish black. Involucrellum carbonized, black, 55$125 \mu \mathrm{m}$ thick. Exciple dense, prosoplectenchymatous, 10-12.5 $\mu \mathrm{m}$ thick, colourless to brown. Interascal filaments: unbranched or simply branched, thin. Asci bitunicate in structure, apex with a non-amyloid rounded, sometimes appearing almost unitunicate in some developmental stages, due to the gradually thinner inner walls (Fig. 1f; Fig. 2h, j), clavate to cylindrical, 75-90 × 10$12.5 \mu \mathrm{m}, \mathrm{I}-, \mathrm{KI}-$, 8-spored. Ascospores fusiform, 3septate, colourless, $25-30 \times 6-8 \mu \mathrm{m}$. Pycnidia common, wart-shaped, immersed to erumpent, 0.05-0.1 mm diam, black. Conidia (microconidia) fusiform, hyaline, nonseptate, $4-5 \times 1.5-2 \mu \mathrm{m}$.

Alga partner. The trentepohlioid genera Cephaleuros, Phycopeltis and Trentepohlia have been reported from Strigulaceae (Lücking 2008; Nelsen et al. 2011b). In addition to morphology, four newly generated ITS sequences of the photobiont were aligned with selected Trentepohliaceae from GenBank; the selected sequences of Cephaleuros, Phycopeltis and Trentepohlia formed separate branches each (Fig. 4), and the photobiont of the new lineage clustered with Phycopeltis.

Chemistry: No substances detected by TLC.

Ecology and distribution: At present, the new species is known only from the type locality (Hainan island) in China, where it grows on leaves in wet tropical forest. 
Remarks: For similarities and differences of the new species with other taxa in Strigulaceae and the unrelated genera Porina and Pocsia, see above.

Other specimens examined: CHINA: Hainan: Changjiang county, Bawangling National Nature Reserve, $19^{\circ} 07^{\prime} 07^{\prime \prime} \mathrm{N}, 109^{\circ} 09^{\prime} 12^{\prime \prime} \mathrm{E}$, alt. $700 \mathrm{~m}$, on living leaves, 4 September 2017, S.H. Jiang HN20171719 (HMAS-L0141342), HN20171740 (HMAS-L0141344), HN20171808 (HMASL0141348), HN20171820 (HMAS-L0141343), HN20171826 (HMAS-L0141349), HN20171844 (HMAS-L0141346), HN20171845 (HMAS-L0139639), HN20171850 (HMASL0141345), HN20171857 (HMAS-L0139640), HN20171875 (HMAS-L0141347).

\section{CONCLUSIONS}

Molecular data of some foliicolous lichens collected in Hainan island revealed a new lineage morphologically similar to Porina but phylogenetically related to Strigulaceae, differing from the latter in ascus type, which merits the status of a new genus (Tenuitholiascus) and family (Tenuitholiascaceae) within Strigulales. The extent of lack of exploration on tropical foliicolous lichens in Asia is indicated by the new genus having been collected 11 times on a single day. Indeed, the discovery of this previously unsuspected lineage is an example of how little we know. It should still be stressed that the effort to complete the inventory of tropical lichens should be made in the future.

\section{Supplementary information}

Supplementary information accompanies this paper at https://doi.org/10. 1186/s43008-019-0026-2.

Additional file 1. Phylogenetic tree constructed from Bayesian analyses in Dothideomycetes and Lecanoromycetes based on four gene (SSU, LSU, TEF1-a, and RPB2) sequences with 4033 bp. Bayesian inference posterior probabilities above $90 \%$ (left) and Maximum likelihood bootstrap probabilities above 50\% (right) are shown at nodes (B-PP / ML-BP). The families and orders including lichenized taxa are marked with *. The tree was rooted to Basidiomycota.

Additional file 2. Alignment of the nuLSU for Strigulaceae and Tenuitholiascaceae to discern diagnostic positions at family level.

\section{Abbreviations}

B-PP: Bayesian posterior probabilities; ML: Maximum likelihood; MLBP: Maximum likelihood bootstrap probabilities; RPB2: The second largest subunit of RNA polymerase II; TEF1-a: Translation elongation factor 1 a

\section{Acknowledgements}

This project supported by the Natural Science Foundation of China $(31750001,31800010)$ are gratefully acknowledged. Sincere thanks to the anonymous reviewers of the manuscript.

\section{Adherence to national and international regulations} Not applicable.

\section{Authors' contributions}

JCW and DLH conceived and designed the project. SHJ performed sampling and phenotypic identification, generated the DNA sequences. SHJ and RL analysed the data. SHJ, RL, DLH and JCW wrote the manuscript. All authors read and approved the final manuscript.

\section{Funding}

This study was supported by Grants 31750001 and 31800010 from the National Natural Science Foundation of China (NSFC).

\section{Availability of data and materials}

The materials are available as Additional files 1 and 2. All sequence data generated for this study (Tables 1 and 2) can be accessed via GenBank: https://www.ncbi.nlm.nih.gov/genbank/. Alignments are available at TreeBase (http://www.treebase.org).

\section{Ethics approval and consent to participate}

Not applicable.

\section{Consent for publication}

Not applicable.

\section{Competing interests}

The authors declare no competing interests.

\section{Author details}

${ }^{1}$ State Key Laboratory of Mycology, Institute of Microbiology, Chinese Academy of Sciences, Beijing, China. ${ }^{2}$ Department of Life Sciences, The Natural History Museum, Cromwell Road, London SW7 5BD, UK. ${ }^{3}$ Comparative Plant and Fungal Biology, Royal Botanic Gardens, Kew, Surrey TW9 3DS, UK. ${ }^{4}$ Jilin Agricultural University, Changchun 130118, Jilin Province, China. ${ }^{5}$ Botanischer Garten und Botanisches Museum, Freie Universität Berlin, Königin-Luise-Straße 6-8, 14195 Berlin, Germany. ${ }^{6}$ University of Chinese Academy of Sciences, Beijing, China.

Received: 8 August 2019 Accepted: 20 December 2019

Published online: 05 February 2020

\section{References}

Andersen HL, Ekman S (2005) Disintegration of the Micareaceae (lichenized Ascomycota): a molecular phylogeny based on mitochondrial rDNA sequences. Mycol Res 109:21-30. https://doi.org/10.1017/S0953756204001625 Aptroot A, Moon KH (2014) 114 new reports of microlichens from Korea, including the description of five new species, show that the microlichen flora is predominantly Eurasian. Herzogia 27:347-365. https://doi.org/10. 13158/heia.27.2.2014.347

Baloch E, Grube M (2006) Evolution and phylogenetic relationships within Porinaceae (Ostropomycetidae), focusing on foliicolous species. Mycol Res 110: 125-136. https://doi.org/10.1016/j.mycres.2005.09.009

Baloch E, Grube M (2009) Pronounced genetic diversity in tropical epiphyllous lichen fungi. Mol Ecol 18:2185-2197. https://doi.org/10.1111/j.1365-294X.2009.04183.x

Baral HO (1987) Lugol's solution / IKI versus Melzer's reagent: hemiamyloidity, a universal feature of the ascus wall. Mycotaxon 29:399-450

Harris RC (1975) A taxonomic revision of the genus Arthopyrenia Massal. s. lat. (Ascomycetes) in North America. PhD Thesis. Michigan State University, Michigan

Harris RC (1995) More Florida lichens: including the 10 C. Tour of the Pyrenolichens. Published by New York Botanical garden, New York, NY Hernández-Restrepo M, Gené J, Castañeda-Ruiz RF, Mena-Portales J, Crous PW, Guarro J (2017) Phylogeny of saprobic microfungi from southern Europe. Stud Mycol 86:53-97. https://doi.org/10.1016/j.simyco.2017.05.002

Huhndorf SM, Harris RC (1996) Oletheriostrigula, a new genus for Massarina papulosa (Fungi, Ascomycetes). Brittonia 48:551-555. https://doi.org/10.2307/2807875

Hyde KD, Jones EBG, Liu JK, Ariyawansa H, Boehm E, Boonmee S, Braun U, Chomnunti P, Crous PW, Dai DQ, Diederich P, Dissanayake A, Doilom M, Doveri F, Hongsanan S, Jayawardena R, Lawrey JD, Li YM, Liu YX, Lücking R, Monkai J, Muggia L, Nelsen MP, Pang KL, Phookamsak R, Senanayake IC, Shearer CA, Suetrong S, Tanaka K, Thambugala KM, Wijayawardene NN, Wikee S, Wu HX, Zhang Y, Aguirre-Hudson B, Alias SA, Aptroot A, Bahkali AH, Bezerra JL, Bhat DJ, Camporesi E, Chukeatirote E, Gueidan C, Hawksworth DL, Hirayama K, Hoog SD, Kang JC, Knudsen K, Li WJ, Li XH, Liu ZY, Mapook A, McKenzie EHC, Miller AN, Mortimer PE, Phillips AJL, Raja HA, Scheuer C, Schumm F, Taylor JE, Tian Q, Tibpromma S, Wanasinghe DN, Wang Y, Xu JC, Yacharoen S, Yan JY, Zhang M (2013) Families of Dothideomycetes. Fungal Divers 63:1-313. https://doi.org/10.1007/s13225-013-0263-4

Jaklitsch W, Baral HO, Lücking R, Lumbsch HT (2016) Syllabus of plant families, 13th edn. A Engler's syllabus der Pflanzenfamilien. 1/2 Ascomycota, Borntraeger, Germany 
Jayalal U, Oh SO, Lücking R, Joshi S, Kim JA, Park JS, Hur JS (2013) Contributions to the foliicolous lichens flora of South Korea. Mycobiology 41:202-209. https://doi.org/10.5941/MYCO.2013.41.4.202

Jiang SH, Wei XL, Wei JC (2016) Strigula sinoaustralis sp. nov. and three Strigula spp. new for China. Mycotaxon 131:795-803. https://doi.org/10.5248/131.795

Jiang SH, Wei XL, Wei JC (2017a) Two new species of Strigula (lichenised Dothideomycetes, Ascomycota) from China, with a key to the Chinese foliicolous species. MycoKeys 19:31-42. https://doi.org/10.3897/mycokeys.19. 11174

Jiang SH, Wei XL, Wei JC (2017b) A new species and two new records of Strigula (lichenized Ascomycota) from China. Mycoscience 58:391-397. https://doi. org/10.1016/j.myc.2017.05.003

Kalyaanamoorthy S, Minh BQ, Wong TKF, von Haeseler A, Jermiin LS (2017) ModelFinder: fast model selection for accurate phylogenetic estimates. Nat Methods 14:587-589. https://doi.org/10.1038/nmeth.4285

Katoh K, Toh H (2010) Parallelization of the MAFFT multiple sequence alignment program. Bioinform 26:1899-1900. https://doi.org/10.1093/bioinformatics/ btq224

Krishnamurthy YL, Kumar SS (2017) Foliicolous lichens of Central Western Ghats, India: Diversity, distribution and molecular study. LAP LAMBERT Academic Publishing, Saarbrücken, p 240

Krishnamurthy YL, Subramanya SK (2016) Phenotype and genotype based cladistic analysis of the genus Strigula (foliicolous lichens) present in the Western Ghats region of Karnataka, India. Int Multidisciplinary Sci GeoConference 3:317-324

Liu YJ, Whelen S, Hall BD (1999) Phylogenetic relationships among ascomycetes: evidence from an RNA polymerase II subunit. Mol Biol Evol 16:1799-1808

Lücking R (2001) Lichens on leaves in tropical rain forests: life in a permanently ephemerous environment. Dissertationes Botanicae 346:41-77

Lücking R (2008) Foliicolous lichenized fungi, vol 103. Published for the organization for Flora Neotropica by the New York Botanical Garden Press, Bronx, NY, pp 1-866

Lücking R, Hodkinson BP, Leavitt SD (2017) The 2016 classification of lichenized fungi in the Ascomycota and Basidiomycota - approaching one thousand genera. Bryologist 119:361-416. https://doi.org/10.1639/0007-2745-119.4.361

Lücking R, Sérusiaux E (2013) Phyllobathelium nudum Zahlbr. Is a second species in the genus Phyllocratera (lichenized Ascomycota: Strigulaceae). Lichenologist 45:691-693. https://doi.org/10.1017/S0024282913000388

Lücking R, Stuart BL, Lumbsch HT (2004) Phylogenetic relationships of Gomphillaceae and Asterothyriaceae: evidence from a combined Bayesian analysis of nuclear and mitochondrial sequences. Mycologia 96:283-294. https://doi.org/10.2307/3762064

Lumbsch HT, Schmitt I, Mangold A, Wedin M (2007) Ascus types are phylogenetically misleading in Trapeliaceae and Agyriaceae (Ostropomycetidae, Ascomycota). Mycol Res 111:1133-1141. https://doi.org/10. 1016/j.mycres.2007.06.016

Miadlikowska J, Kauff F, Högnabba F, Oliver JC, Molnár K, Fraker E, Gaya E, Hafellner J, Hof-stetter V, Gueidan C, Kukwa M, Lücking R, Björk C, Sipman HJM, Burgaz AR, Thell A, Passo A, Myllys L, Goward T, Fernández-Brime S, Hestmark G, Lendemer J, Lumbsch HT, Schmull M, Schoch C, Sérusiaux E, Maddison DR, Arnold AE, Lutzoni F, Stenroos S (2014) A multigene phylogenetic synthesis for the class Lecanoromycetes (Ascomycota): 1307 fungi representing 1139 infrageneric taxa, 312 genera and 66 families. Mol Phylogenet Evol 79:132-168. https://doi.org/10.1016/j.ympev.2014.04.003

Minter DW, Peredo HL, Watson AT (2007) Acrospermum chilense sp. nov. from Chile and the Acrospermales Ord. Nov. Boletín de la Sociedad Argentina de Botánica 42:107-112

Nelsen MP, Lücking R, Grube M, Mbatchou JS, Muggia L, Plata ER, Lumbsch HT (2009) Unravelling the phylogenetic relationships of lichenised fungi in Dothideomyceta. Stud Mycol 64:135-144. https://doi.org/10.3114/sim. 2009.64.07

Nelsen MP, Lücking R, Mbatchou JS, Andrew CJ, Spielmann AA, Lumbsch HT (2011a) New insights into relationships of lichen-forming Dothideomycetes. Fungal Divers 51:155-162. https://doi.org/10.1007/s13225-011-0144-7

Nelsen MP, Plata ER, Andrew CJ, Lücking R, Lumbsch HT (2011b) Phylogenetic diversity of trentepohlialean algae associated with lichen-forming fungi. J Phycol 47:282-290

Nguyen LT, Schmidt HA, von Haeseler A, Minh BQ (2015) IQ-TREE: a fast and effective stochastic algorithm for estimating maximum-likelihood phylogenies. Mol Biol Evol 32:268-274. https://doi.org/10.1093/molbev/ msu300
Orange A, James PW, White FJ (2001) Microchemical methods for the identification of lichens. British Lichen Society, London

Papong K, Corush J, Mangold A, Lücking R, Lumbsch HT (2009) Phylogenetic position of the foliicolous genus Chroodiscus (Ostropales, Ascomycota) inferred from nuclear and mitochondrial ribosomal DNA sequences. Fungal Divers 38:147-153

Piercey-Normore MD, Depriest PT (2001) Algal switching among lichen symbioses. Am J Bot 88:1490-1498. https://doi.org/10.2307/3558457

Rambaut A (2012) FigTree v1.4.2, available from: http://tree.bio.ed.ac.uk/software/ figtree/

Rehner SA, Buckley E (2005) A Beauveria phylogeny inferred from nuclear ITS and EF1-a sequences: evidence for cryptic diversification and links to Cordyceps teleomorphs. Mycologia 97:84-98. https://doi.org/10.1080/15572536.2006. 11832842

Rogers SO, Bendich AJ (1988) Extraction of DNA from plant tissues. In: Gelvin SB, Schilperoort RA, Verma DPS (eds) Plant Molecular Biology manual, vol A6. Kluwer Academic Publishers, Dordrecht, pp 1-10

Ronquist F, Teslenko M, Mark PVD, Ayres DL, Darling A, Hohna S, Larget B, Liu L, Suchard MA, Huelsenbeck JP (2012) MrBayes 3.2: efficient Bayesian phylogenetic inference and model choice across a large model space. Syst Biol 61:539-542. https://doi.org/10.1093/sysbio/sys029

Roux C, Sérusiaux E, Bricaud O, Coppins B (2004) Le genre Strigula (lichens) en Europe et en Macaronésie. Bibliotheca Lichenologica 90:1-196

Santesson R (1952) Foliicolous lichens I. a revision of the taxonomy of the obligately foliicolous, lichenized fungi. Symbolae Botanicae Upsalienses 12:1590

Sobreira PNB, Cáceres MES, Maia LC, Lücking R (2018) Flabelloporina, a new genus in the Porinaceae (Ascomycota, Ostropales), with the first record of $F$. squamulifera from Brazil. Phytotaxa 358:67-75. https://doi.org/10.11646/ phytotaxa.358.1.4

White TJ, Bruns TD, Lee SB, Taylor JW (1990) Amplification and direct sequencing of fungal ribosomal RNA genes for phylogenetics. In: Innis MA et al (eds) PCR protocols: a guide to methods and applications. Academic press, New York, pp 315-322

\section{Publisher's Note}

Springer Nature remains neutral with regard to jurisdictional claims in published maps and institutional affiliations.

Ready to submit your research? Choose BMC and benefit from

- fast, convenient online submission

- thorough peer review by experienced researchers in your field

- rapid publication on acceptance

- support for research data, including large and complex data types

- gold Open Access which fosters wider collaboration and increased citations

- maximum visibility for your research: over $100 \mathrm{M}$ website views per year

At BMC, research is always in progress.

Learn more biomedcentral.com/submissions 